\title{
SISTEM PAKAR DIAGNOSA PENYAKIT YANG DISEBABKAN PARASIT PADA HEWAN PELIHARAAN ANJING BERBASIS WEB
}

\author{
Enny Dwi Oktaviyani ${ }^{\mathrm{a}, 1, *}$, Sherly Christina ${ }^{\mathrm{b}, 2}$, Agry Nugraha ${ }^{\mathrm{c}, 3}$ \\ ${ }^{a}$ Universitas Palangka Raya, J1. H. Timang \\ ${ }^{\mathrm{b}}$ Universitas Palangka Raya, Jl. H. Timang \\ ${ }^{c}$ Universitas Palangka Raya, Jl. H. Timang \\ ${ }^{1}$ enny.obrien@gmail.com *; ${ }^{2}$ sherly.christina.upr@gmail.com; ${ }^{3}$ pranugatama@gmail.com \\ * corresponding author
}

ARTICLE INFO

\section{Keywords}

Expert System

BayesTheorem

Forward Chaining

Parasites

Dog

\section{ABSTRACT}

The issue addressed in this research is how to design and build an expert system which capable of diagnosing dog diseases that are caused by parasites, and how this expert system later can be useful for dog owners. This expert system is developed based on website technology in order to ease the accessibility for the users. The finished product is expected to become useful for dog owners, to help them diagnose their dog disease based on the symptoms in order to give the proper treatment. The software development methodology used to develop this expert system is the Waterfall methodology, while the design is done using Unified Modeling Language (UML). The programming language is PHP for the logic and MySQL for the database, and the finished product is then tested using black box testing method. To test system accuracy, disease diagnosis results from the expert system is then compared with diagnosis results from the real human expert (veterinarian).

This expert system is using forward chaining method and Bayes theorem. The forward chaining concept, in this system, starting with the symptoms that are set into a reasoning and rules to reach some conclusions which in this case are the possible diseases. While the Bayes theorem is used to draw a conclusion from the possible diseases. This expert system, however, still can be developed not only to diagnose diseases that are caused by parasites, but also to diagnose all kind of dog diseases

\section{Pendahuluan}

\subsection{Latar Belakang}

Anjing merupakan salah satu jenis hewan peliharaan yang paling banyak digandrungi dan dipelihara oleh pemelihara hewan, selain karena sifat penurut dan setianya hewan bernama ilmiah Canis Lupus Familiaris memiliki presentase nilai terbaik untuk penghilang stress bagi pemeliharanya. Memelihara anjing memang memiliki banyak manfaat, akan tetapi memelihara anjing memiliki banyak resiko diantaranya ialah anjing merupakan satu jenis hewan peliharaan yang paling mudah terkena penyakit, penyakit anjing biasanya didapat karena kurangnya kebersihan dari anjing itu sendiri.Berbagai macam penyakit disebabkan oleh adanya parasit yang menempel pada anjing jika tidak cepat ditangani anjing akan mengidap penyakit yang lebih serius yang dapat menyebabkan kematian bagi anjing peliharaan

Hal inilah yang menjadi masalah, adanya keterbatasan pengetahuan pemelihara tentang jenis parasit dan penyakit yang diakibatkanya, serta adanya keterbatasan dokter hewan pada lokasi atau tempat tertentu dan juga biaya yang tidaklah sedikit untuk menggunakan jasa ahli/dokter hewan membuat kebanyakan pemelihara anjing membiarkan anjing sakit dengan hanya mengobati namun 
tidak sesuai dengan penyakit yang diderita, hal inilah yang membuat tingkat kematian hewan peliharaan akibat parasit juga cukup tinggi. Tentunya sangat penting bagi pemelihara anjing agar memiliki wawasan yang lebih untuk mengenali serta menangani lebih dini untuk penyakit akibat parasit pada anjing. Maka untuk mengatasi masalah tersebut tentunya dibutuhkan sebuah sistem pakar yang berkaitan dengan penyakit akibat parasit pada hewan peliharaan anjing yang dapat dimanfaatkan oleh pemelihara anjing dalam memelihara maupun mendeteksi jenis penyakit yang diakibatkan oleh parasit pada anjing.

Pembuatan aplikasi sistem pakar untuk mendiagnosis penyakit anjing yang diakibatkan oleh parasit berbasis web ini akan memudahkan para pemelihara anjing dalam mendeteksi sejak dini jenis penyakit serta parasit yang mengakibatkannya tanpa harus bergantung pada dokter hewan untuk penanganan lebih dini. Dengan adanya aplikasi berbasis web ini diharapkan dapat membantu meningkatkan pengetahuan dari pemelihara anjing dalam menangani jenis penyakit akibat parasit pada anjing peliharaannya. Dimana pada pengerjaan penelitian mengenai sistem pakar tersebut dihasilkan aturan dan rule tertentu yang digunakan untuk menentukan jenis penyakit akibat parasit serta jenis parasit yang menempel pada anjing.

\subsection{Manfaat Penelitian}

Manfaat yang dapat diperoleh dari penelitian ini, yaitu dapat menjadi suatu referensi untuk mengetahui penyakit yang dialami oleh anjing dan penanganannya berdasarkan pengetahuan yang didapat dari seorang pakar.

\subsection{Tinjauan Pustaka}

1. Konsep Umum Sistem Pakar

Sistem pakar merupakan sistem yang berusaha mengadopsi pengetahuan manusia ke komputer, agar komputer dapat menyelesaikan masalah seperti yang biasa dilakukan oleh para ahli . Fungsi utamanya adalah agar orang awampun dapat menyelesaikan masalah yang cukup rumit yang sebenarnya hanya bisa di pecahkan para ahli. Sistem pakar yang diterapkan pada penelitian ini berjenis MYCIN yang digunakan untuk mendiaknosa penyakit. Adapun sruktur sistem pakar ialah sebagai berikut (Sri Kusumadewi, 2003)

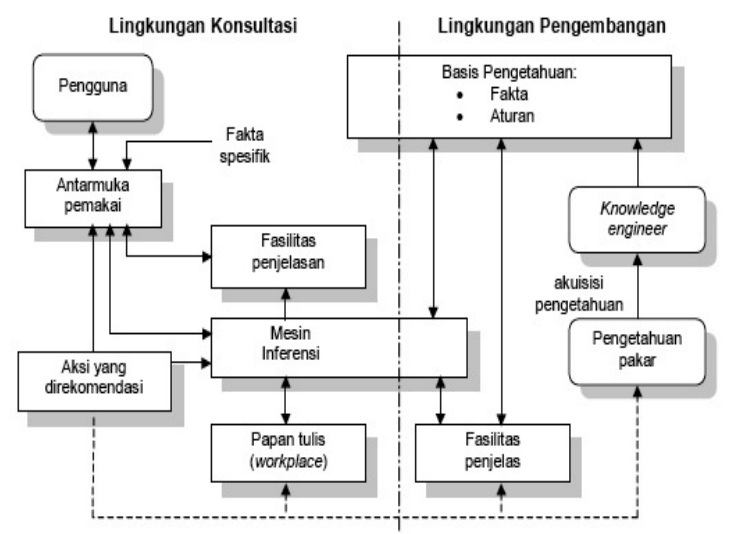

Gambar 1.Struktur Sistem Pakar ( Sri Kusumadewi , 2003) 


\section{JURNAL TEKNOLOGI INFORMASI}

[E-ISSN 2656-0321]

[Vol 12. No. 1]

Jurnal Keilmuan dan Aplikasi Bidang Teknik Informatilka

[Januari 2018]

2. Basis Pengetahuan

Merupakan salah satu bentuk representasi pengetahuan yang banyak digunakan dalam pengembangan sistem pakar. representasi pengetahuan dengan penalaran berbasis aturan rule-basereasoning berupa aturan IF-THEN.bentuk ini digunakan apabila kita memiliki sejumlah pengetahuan pakar pada suatu permasalahan tertentu dan sipakar dapat menyelesaikan masalah tersebut secara berurutan, selain itu bentuk ini juaga digunakan apabila dibutuhkan penjelasan tentang jejak (langkah) pencapaian solusi. Berikut ini merupakan contoh penerapan basis pengetahuan (Sri Kusumadewi, 2003):

- Rule 1

IF Anjing Menggaruk Berlebih

AND Bintik Gelap Pada Bulu

AND Anjing Mengalami Anemia

AND Anjing Terlihat Lemas/Malas Gerak

AND Anjing Demam

AND Hilang Selera Makan

AND Banyak Caplak

THENRocky Montain

3. Mesin Inferensi

Motor inferensi yang digunakan adalah forward chaining yang merupakan motor inferensi yaitu berisikan pencocokan melalui penalaran yang dibentuk sedemikian rupa dengan dimulai dari fakta untuk menguji kebenaran hipotesis (Sri Kusumadewi, 2003). Contoh penerapannya aturanaturan :

\begin{tabular}{|c|l|}
\hline No & \multicolumn{1}{|c|}{ Aturan } \\
\hline R-1 & IF A \& B THEN C \\
\hline R-2 & IF C THEN D \\
\hline R-3 & IF A \& E THEN F \\
\hline R-4 & IF A THEN G \\
\hline R-5 & IF F \& G THEN D \\
\hline R-6 & IF G \& E THEN H \\
\hline R-7 & IF C \& H THEN I \\
\hline R-8 & IF I \& A THEN J \\
\hline R-9 & IF G THEN J \\
\hline R-10 & IF J THEN K \\
\hline
\end{tabular}

\begin{tabular}{|c|c|c|}
\hline & Aturan & Fakia Baru \\
\hline$\rightarrow \sqrt[U]{n^{n}}$ & $R \cdot 3$ & $F$ \\
\hline & R.4 & G \\
\hline$H^{H}$ & $R \cdot 5$ & $D$ \\
\hline & $R \cdot 6$ & $H$ \\
\hline & $R \cdot g$ & $J$ \\
\hline & $R \cdot 10$ & $K$ (tertoukti) \\
\hline
\end{tabular}

4. Metode Teorema Bayes

Menurut , Sri Kusumadewi (2003) ,Probabilitas bayes merupakan salah satu cara untuk

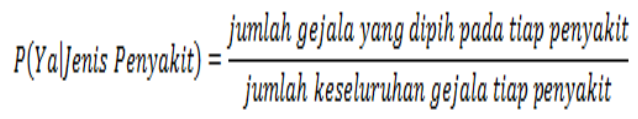

mengatasi ketidakpastian data dengan menggunakan formula bayes, selain itu pada buku Rika Rosnelly (2012: 79-81) juga menerapkan rumus yang sama dengan keterangan yang sama :

$$
p(H i \mid E)=\frac{p(E \mid H i) * p(H i)}{\sum_{k=1}^{n} p(E \mid H k) * p(H k)}
$$


dengan :

- $p(H i \mid E)=$ probabilitas hipotesi Hi benar jika diberikan evidence $\mathrm{E}$

$$
P(Y A)=P(\text { Ya|Jenis Penyakit } 1) * P(\text { Jenis Penyakit } 1) \ldots \ldots \ldots . . . n
$$

- $p(E \mid H i)=$ probabilitas munculnya evidence $\mathrm{E}$, jika diketahui hipotesis $\mathrm{Hi}$

- $p(H i)=$ probabilitas hipotesis Hi (menurut hasil sebelumnya) tanpa memandang evidence apapun

- $n=$ jumlah hipotesis yang mungkin

$$
P(\text { Jenis Penyakit } \mid Y A)=\frac{P(\text { Yaljenis Penyakit }) * P(\text { Jenis Penyakit })}{P(Y A)}
$$

Hartatik dan Iketut Putra Yasa (2015) ada beberapa langkah dalam metode teorema bayes . Langkah awal dari metode teorema bayes adalah mencari nilai jawaban "ya" pada tiap jenis penyakit anjing. adapun bentuk rumusannya ialah sebagai berikut :

a. Penerapan Rumus Probabilitas :

Penerapan Rumus Probabilitas ini dilakukan untuk menentukan tingkat probabilitas dari gejala (Probabilitas munculnya evidence E, jika diketahui Hipotesis $\mathrm{H}$ benar dan juga probabilitas hipotesis $\mathrm{H}$ tanpa memandang gejala apapun. Hal ini dilakukan dikarenakan data yang dibuat untuk penelitian ini bersifat data sampel (sementara) . Maka diterapkan rumus Probabilitas Umum seperti berikut :

b. Setelah didapatkan jawaban "ya" pada tiap penyakit, langkah selanjutnya menghitung nilai semua "ya" pada seluruh gejala pada semua penyakit

c. Langkah terakhir ialah dengan menghitung nilai probabilitas jawaban Ya pada tiap jenis penyakit sehingga menghasilkan perbandingan probabilitas dan yang tertinggi adalah tingkat presentase probabilitas paling besar:

Catatan : Nilai Kebenaran suatu probabilitas tingkat kepastian paling tinggi adalah 1 dan terendah adalah 0 , jika di presentasekan semua nilai probabilitas tiap gejala jika dijumlahkan maka akan mendapatkan poin $100 \%$.

\section{Kecerdasan Buatan}

Secara umum, kecerdasan buatan (Artificial Intelligencel AI), yaitu intelligence adalah kata sifat berarti cerdas, sedangkan artificial artinys buatan. Kecerdasan buatan yang dimaksud merujuk pada mesin yang mampu berfikir, menimbang tindakan yang akan diambil, dan mampu mengambil keputusan seperti yang dilakukan oleh manusia. Berikut ini adalah perbedaan antara kecerdasan alami dan kecerdasan buatan.

Kecerdasan buatan lebih bersifat permanen. Kecerdasan alami akan cepat mengalami perubahan. Kemampuan kecerdasan buatan tidak akan pernah berubah selama programnya tidak diubah oleh programmer, berbeda dengan kecerdasan alami. Karena sifat manusia yang subjektif, pelupa, dan semakin lama semakin tua sehingga kemampuan berpikirnya berkurang seiring dengan bertambahnya waktu, kemampuan kecerdasan alami cenderung tidak permanen.

Kecerdasan alami lebih mudah untuk dipublikasikan. Misalnya saja pemerintah membutuhkan 10.000 orang pakar penyakit jantung untuk ditempatkan diseluruh Indonesia. Bayangkan kalau pemerintah harus menyekolahkan anak bangsa sejumlah 10.000 orang, mulai dari SD sampai lulus sarjana kedokteran sepesialis jantung. Waktu yang dibutuhkan minimal 20 tahun. Sementara itu untuk kecerdasan buatan, pemerintah cukup membuat satu sistem pakar penyakit jantung dengan waktu 


\section{JURNAL TEKNOLOGI INFORMASI}

[E-ISSN 2656-0321]

[Vol 12. No. 1]

Jurnal Keilmuan dan Aplikasi Bidang Teknik Informatilka

[Januari 2018]

yang relatif lebih cepat dan biaya yang jauh lebih murah. Proses duplikasi dan pendistribusiannya ke seluruh pelosok tanah air pun sangat mudah (Sri Kusumadewi, 2003)

\section{MetodologiPenelitian}

Metodologi penelitian yang digunakan adalah sebagai berikut :

1. Metode Analisis (Teknik Wawancara)

Adapun metode analisis yang digunakan dalam sistem pakar ini adalah dengan proses wawancara. yaitu proses Tanya jawab secara langsung terhadap Pakar dalam perancangan Penelitian tentang "Sistem Pakar Diagnosa Penyakit Yang disebabkan Parasit Pada Hewan Peliharaan Anjing Berbasis Web" yaitu Bapak Drh. Eko Hari Yuwono.

2. Alat dan Bahan

Hardware : 1 unit laptop TOSHIBA dengan spesifikasi :

a. Processor : Intel $R$ Core i3-2348M

b. RAM 2 GB (1,88 GB Usable $)$

c. $O S$ : Windows 7

3. Metode Pengembangan Perangkat Lunak

Metodologi pelaksanaan penelitian yang digunakan adalah metode siklus waterfall.

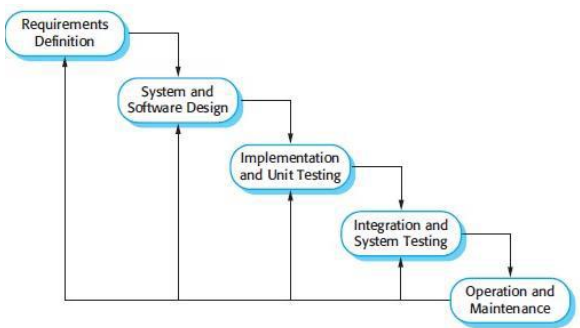

Gambar 2 Waterfall(Sommerville, 2011)

\section{a. Requirement Analysis and Definition}

Tahapan ini merupakan awal yang harus diperhatikan terutama dalam menganalisis dan mengkaji masalah dan kebutuhan, serta memutuskan apakah dari permaslahan yang terjadi dengan menerapkan sistem pakar akan membantu atau tidak. Pada tahapan ini menggunakan UML (Unifield Modeling Language)

\section{b. System and Software Design}

Pada tahap ini berguna untuk melakukan pendesainan interface web yang akan dibuat dan disesuai dengan kebutuhan pengguna. Dalam tahapan ini akan dibentuk suatu arsitektur sistem berdasarkan persyaratan yang telah ditetapkan. Dan juga mengidentifikasi dan menggambarkan abstraksi dasar sistem perangkat lunak dan hubungan-hubungannya

\section{c. Implementation and Unit Testing}

Desain yang digunakan kemudian diatur dan diterapkan proses coding dengan bahasa yang dimengerti oleh sistem komputer, yaitu kedalam bahasa pemrograman HTML, PHP, CSS, Bootsrap ,javascript dan My SQl Dalam proses programming tahap ini merupakan implementasi dari tahap desain yang secara teknis akan dikerjakan oleh programmer. Selain itu juga menggunakan database yang berasal dari MySql. Dalam melakukan proses coding juga dilakukan proses testing untuk menguji dan melihat kesalahan yang ada pada program maupun fungsi dari sistem.

\section{d. Integration and System Testing \\ 1. Blackbox Testing}


yaitu pengujian yang menerapkan proses uji pada setiap fungsi yang dirancang, kebenaran dari perangkat lunak dibuat hanya dilihat berdasarkan keluaran yang dihasilkan dari data masukan yang diberikan tanpa melihat bagaimana proses tersebut bekerja didalamnya, dari keluaran dapat disimpulkan hasil dan diketahui kesalahan-kesalahannya.

2. Pengujian Sistem Dengan Pakar Ahli (Perbandingannya)

\section{e. $\quad$ Operation and Maintenance}

Dalam tahapan ini, sistem diinstal dan mulai digunakan. Selain itu juga memperbaiki error yang tidak ditemukan pada tahap pembuatan. Dalam tahap ini juga dilakukan pengembangan sistem seperti penambahan fitur dan fungsi baru

\section{Hasil dan Pembahasan}

a. Struktur Sistem Pakar

Sistem Pakar Diagnosa Penyakit Yang di Akibatkan Parasit PPada Hewan Peliharaan Anjing Berbasis Web" menggunakan metode bayes, berikut ini merupakan struktur penalaran sistem yang akan di buat.

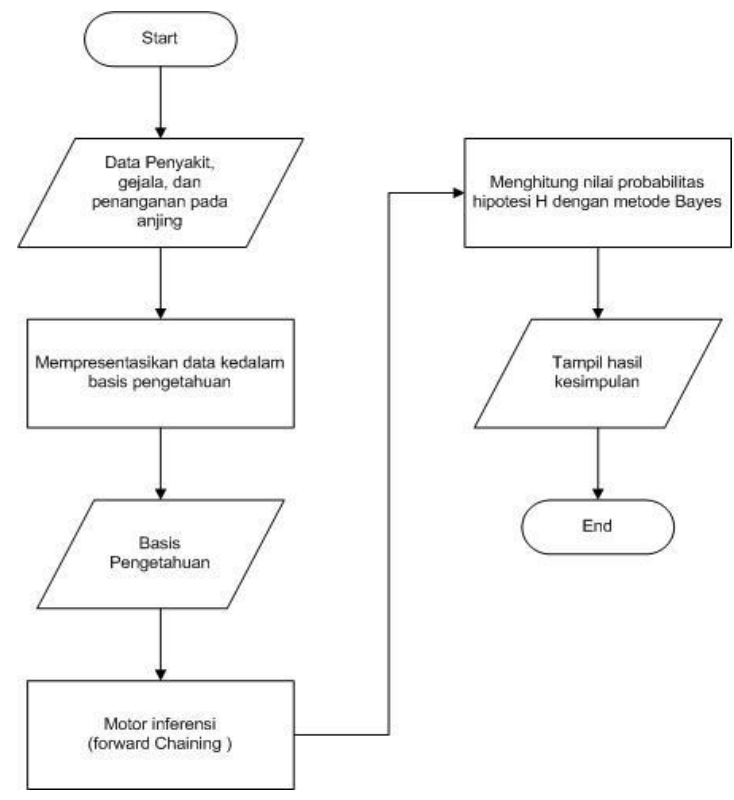

Gambar 3. Struktur Sistem Pakar

Dari struktur sistem pakar tersebut dapat dijelaskan prosesnya adalah sebagai berikut:

1. Memasukan nilai pengetahuan atau memperluas pengetahuan dalam basis pengetahuan. Dimana pengetahuan tersebut diperoleh dari ahli, dalam hal ini ahli atau pakar yang bekerja sama adalah Drh. Eko H.Yuwono berupa dalam file ataupun wawancara langsung.

2. Proses selanjutnya ialah mempresentasikan pengetahuan tersebut kedalam basis pengetahuan yaitu untuk memahami, memperluas dan menyelesaikan suatu masalah menggunakan basis pengetahuan ( Rule- Based Reasoning).

3. Motor inferensi yaitu berisikan pencocokan melalui penalaran yang dibentuk sedemikian rupa dengan dimulai dari fakta untuk menguji kebenaran hipotesis ( forward chaining).

4. Menghitung nilai kepastian dengan menggunakan metode bayes

5. Hasil akan ditampilkan. selesai

b. Basis Pengetahuan (Knowledge base) 
Merupakan salah satu aturan bentuk representasi pengetahuan yang banyak digunakan dalam pengembangan sistem pakar. Representasi pengetahuan dengan Penalaran Berbasis Aturan rule-based reasoning, berupa aturan (rule) yang menerapkan IF-THEN.

Tabel 1.Contoh Penyakit dan Kodenya

\begin{tabular}{cc}
\hline & NAMA JENIS PENYAKIT \\
\hline KODE & Ehrlichiosis \\
\hline PE1 & Babesiosis \\
\hline PE3 & Cacing Pita/Cestoda \\
\hline PE4 & Giardiasis \\
\hline PE5 & Cryptosporidiosis \\
\hline PE6 & Ascariasis \\
\hline PE7 & Cacing Tambang/Ancylostomiasis \\
\hline PE8 & Cacing Jantung/heartworm \\
\hline PE9 & Leptospirosis \\
\hline PE10 & Ear Mite \\
\hline PE11 & Demodex \\
\hline PE12 & Scabies \\
\hline PE13 & Ringworm \\
\hline PE14 & Dermatitis \\
\hline
\end{tabular}

Tabel .2 Contoh Gejala Dan Kodenya

\begin{tabular}{cc}
\hline KODE & GEJALA \\
\hline G1 & Muntah (karna Mag/tidak mau makan/lainnya) \\
\hline G2 & Anjing terlihat cemas \\
\hline G3 & Diare (Sering Berak/Tak terkendali) \\
\hline G4 & Menggigil \\
\hline G5 & Leleran pada hidung (lender/ingus/nanah) \\
\hline G6 & Kulit Anjing Erosi/Merosot/kendor \\
\hline G7 & Bernanah daerah selangkangan \\
\hline G8 & Gusi Pucat/ selaput lendir menguning \\
\hline G9 & Demam/suhu tubuh meningkat \\
\hline G10 & Urine Kuning pekat/ kemerahan \\
\hline G11 & Bulu berdiri (berwarna kusam) \\
\hline G12 & Pertumbuhan terhambat \\
\hline G13 & Mata berair (memerah, terdapat kotoran mata) \\
\hline G14 & Dehidrasi (kekurangan cairan, tidak kosumsi \\
& air) \\
\hline G15 & Perut Buncit/membesar \\
\hline G16 & Sering menggosokan pantat (gatal/dianus \\
& banyak anak cacing) \\
\hline G17 & pada feses seperti ada butiran beras/wijen \\
& kecil-kecil \\
\hline G18 & Anjing mengalami Batuk \\
\hline G19 & Mimisan (keluar darah dari bagian tertentu) \\
\hline
\end{tabular}

Berdasarkan tabel diatas dibentuk sebuah rule untuk membentuk pohon keputusan sesuai dengan gejala yang ada pada penyakit menuju kesimpulan yaitu diagnosa penyakit. Rule pohon keputusan dibentuk dengan cara disusun berdasarkan gejala yang paling banyak muncul dari tiap penyakit 


\section{JURNAL TEKNOLOGI INFORMASI}

[E-ISSN 2656-0321]

[Vol 12. No. 1]

Jurnal Keilmutun dan Aplikasi Bidang Teknik Informatikika

[Januari 2018]

sampai dengan gejala yang hanya ada pada penyakit tersebut. berikut ini merupakan gejala yang paling sering muncul dari tiap penyakit :

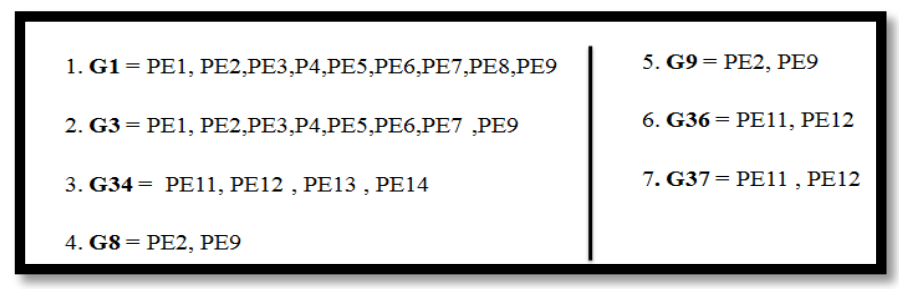

Dari gejala diatas dibentuk sebuah rule pohon keputusan berdasarkan gejala terbanyak yang muncul pada penyakit sampai dengan gejala yang hanya ada pada penyakit tersebut. Berikut ini ilah bentuk rule pohon keputusannya :

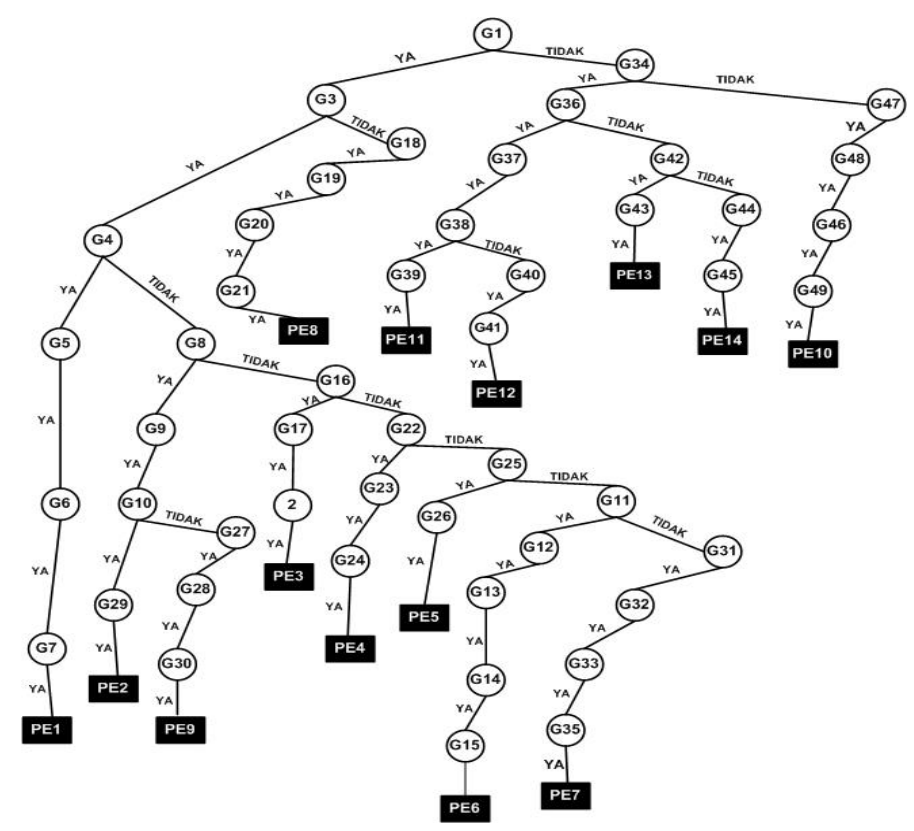

Gambar 4. Pohon Keputusan Dengan Konsep Forward Chaining

\section{c. Metode Forward Chaining}

Motor inferensi yang digunakan adalah forward chaining yang merupakan motor inferensi yaitu berisikan pencocokan melalui penalaran yang dibentuk sedemikian rupa dengan dimulai dari fakta untuk menguji kebenaran hipotesis .(Sri Kusumadewi, 2003). berikut ini merupakan bentuk struktur forward chaining sistem pakar diagnosa penyakit yang disebabkan parasis pada hewan peliharaan anjing berbasis web : 


\section{JURNAL TEKNOLOGI INFORMASI}

[E-ISSN 2656-0321]

[Vol 12. No. 1]

Jurnal Keilmutan dan Aplikasi Bidang Teknik Informatika

[Januari 2018]

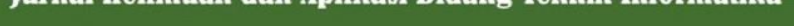

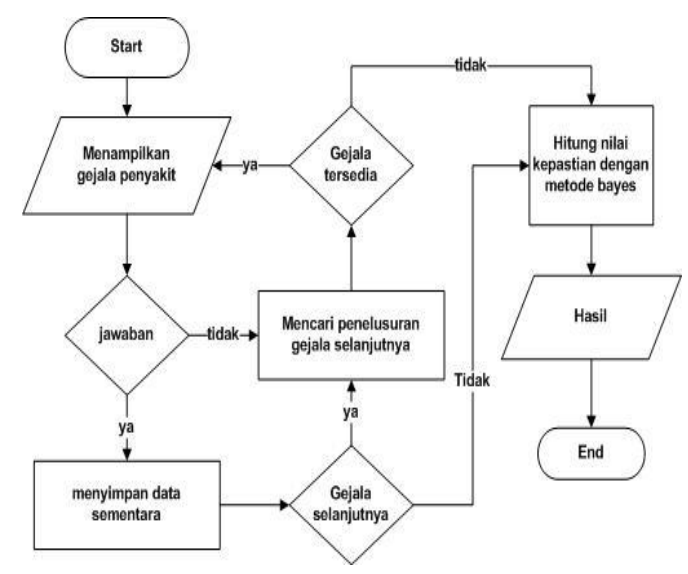

Gambar 5. Penerapan Forward chaining

d. Teorema Bayes

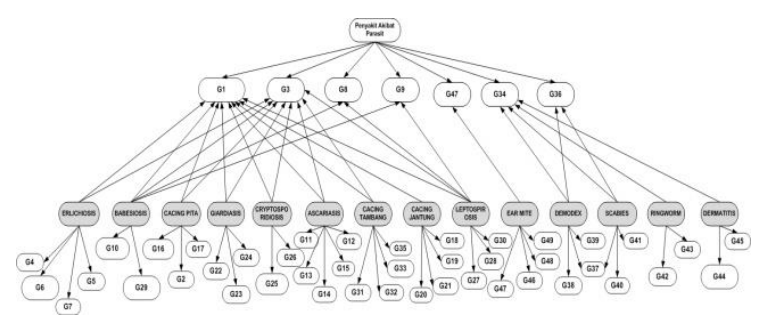

Gambar 6. Struktur Bayes Network Penyakit Parasit Pada Anjing

Network Bayes mempresentasikan tentang adanya hubngan antara kebergantungan langsung dan dapat juga di interpretasikan sebagai pengaruh (sebab akibat) Langsung antara variable yang dihubungkannya. Gambar diatas ialah Representasi dari Network Bayes Sistem Pakar Yang Di akibatkan parasi pada hewan peliharaan anjing (hubungan antara gejala dan penyakit)

Nilai parameter atau nilai kepercayaan dari gejala penyakit merupakan nilai yang muncul untuk menjelaskan nilai kepercayaan dari setiap penyakit yang disebabkan parasit pada anjing, untuk setiap nilai kepercayaan dibuat berdasarkan nilai interval kepercayaan 0,0 sampai dengan 1,0 . Nilai kepercayaan tersebut dibuat berdasarkan kemungkinan nilai dipersentasekan jika nilai 0,0-0,2 (Nilai Kepercayaan 0\% - 20\%), jika nilai 0,3 - 0,4 (Nilai Kepercayaan 30\% - 40\%), jika nilai 0,5 - 0,6 (Nilai Kepercayaan 50\% -60\%), jika nilai 0,7 - 0,8 ( Nilai Kepercayaan 70\% - 80\%), jika nilai 0,9 - 1,0 ( Nilai Kepercayaan 90\% - 100\% ). Akan teteapi nilai kepercayaan ini tidak dapat dinilai penuh karena dalam sistem pakar yang dibuat untuk menilai diagnosa penyakit berdasarkan gejala yang bisa dilihat atau di cari tau oleh orang awam, sementara gejala yang spesifik tidak dimasukan . Berikut ini nilai Parameter yang menjadi acuan dalam Sistem Pakar ini :

Tabel 3. Interpretasi Nilai

\begin{tabular}{cc}
\hline NILAI BAYES & TEOREMA BAYES \\
\hline $0,0-0,2$ & TIDAK ADA \\
\hline $0,3-0,4$ & MUNGKIN \\
\hline $0,5-0,6$ & KEMUNGKINAN BESAR \\
\hline $0,7-0,8$ & HAMPIR PASTI \\
\hline $0,9-1,0$ & PASTI \\
\hline
\end{tabular}


e. Use Case Diagram Admin

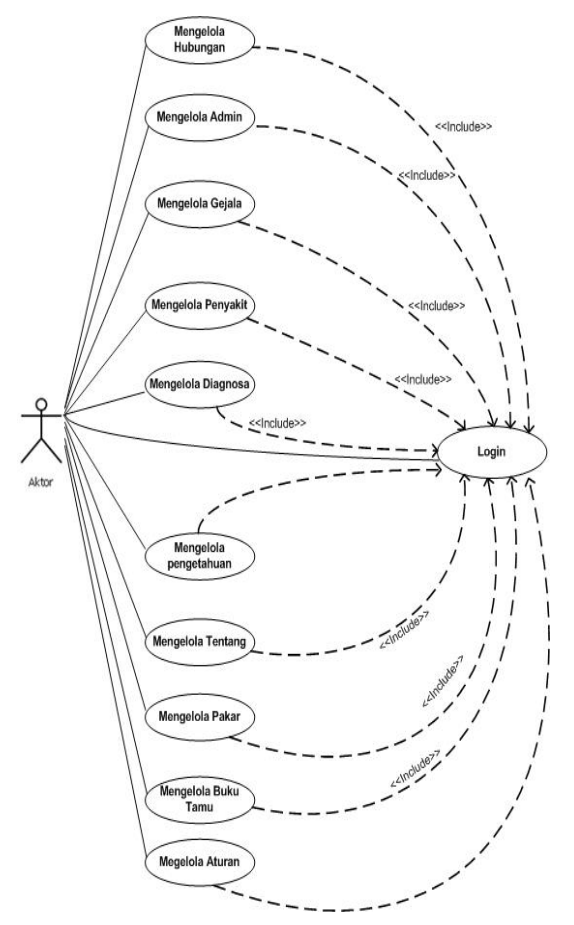

Gambar 7. Use Case Diagram Admin

f. Use Case Pengunjung

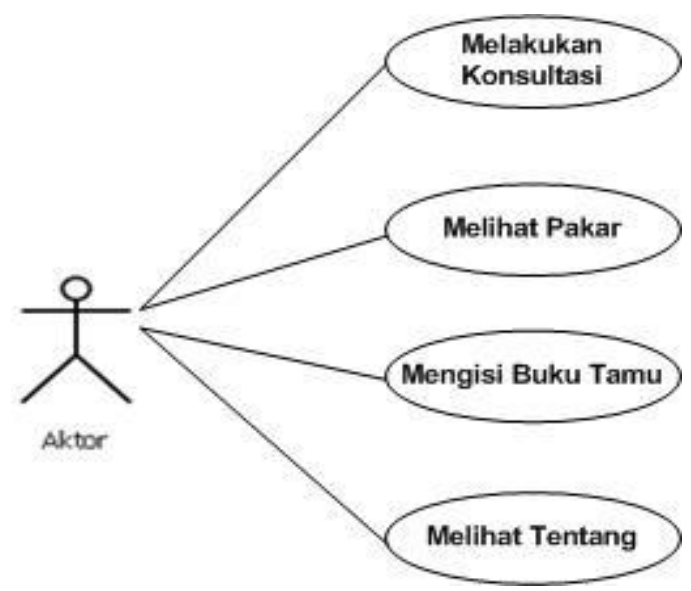

Gambar 8. Usecase Diagram Pengunjung

\section{g. Activity Diagram}

Activity Diagram menggambarkan berbagai alur aktivitas dalam sistem yang sedang dirancang. Bagaimana masing masing alur berawal, bagaimana proses yang mungkin terjadi, dan bagaimana mereka berakhir. 


\section{JURNAL TEKNOLOGI INFORMASI}

h. Implementasi Antarmuka

Merupakan penerapan terdahadap proses interface pada Analisis dan desain. Pada bagian ini semua tahap implementasi desain interface akan dijelaskan dan sesuaikan ( Admin dan Pengunjung).

1. Implementasi Antarmuka Menu Admin

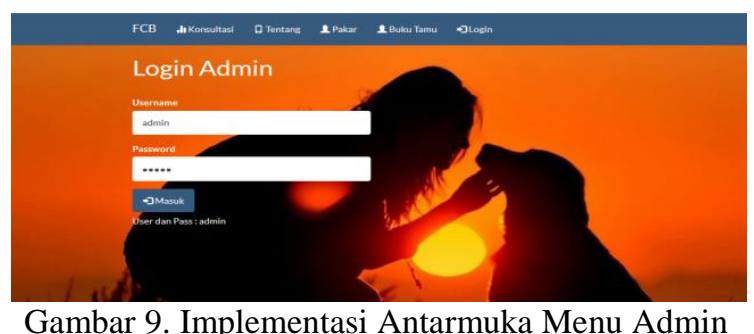

Merupakan bagian halaman login admin, sebelum masuk untuk mengelola sistem pakar. Pada bagian ini admin diharapkan memasukan Username dan Password. Jika salah maka akan muncul error Handling.

\section{Halaman Keloa Gejala}

Merupakan Halaman Untuk Mengelola Gejala pada sistem. Pada bagian ini terdapat beberapa fitur yaitu tambah,ubah dan hapus

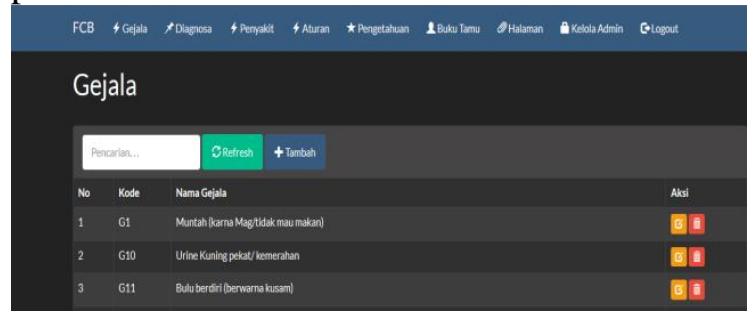

Gambar 10. Halaman Kelola Gejala

3. Halaman Kelola Penyakit

Merupakan Halaman Untuk Mengelola jenis Penyakit pada sistem. Pada bagian ini terdapat beberapa fitur yaitu tambah,ubah dan hapus

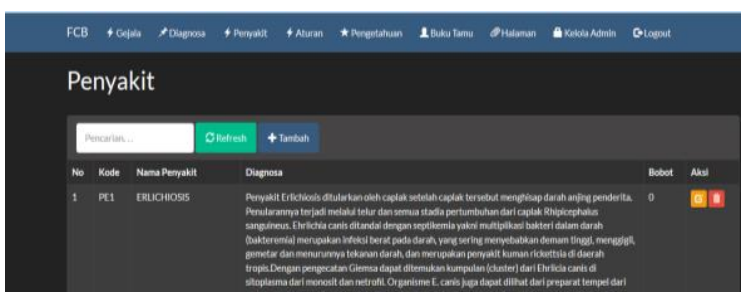

Gambar 11. Halaman Kelola Penyakit

4. Halaman Kelola Diagnosa

Merupakan Halaman Untuk Mengelola Diagnosa pada sistem. Pada bagian ini terdapat beberapa fitur yaitu tambah,ubah dan hapus 


\section{JURNAL TEKNOLOGI INFORMASI}

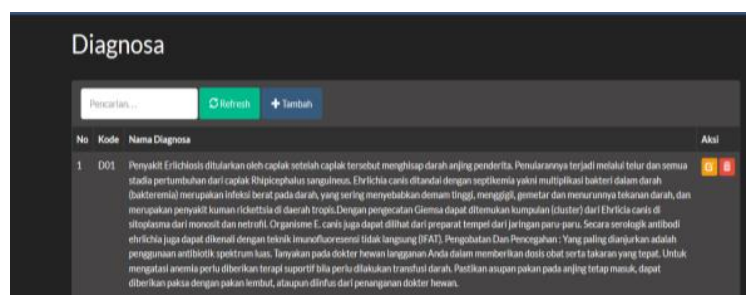

Gambar 12. Halaman Kelola Diagnosa

5. Halaman Kelola Pengetahuan

Merupakan Halaman Untuk Mengelola jenis Pengetahuan pada sistem. Pada bagian ini terdapat beberapa fitur yaitu tambah,ubah dan hapus

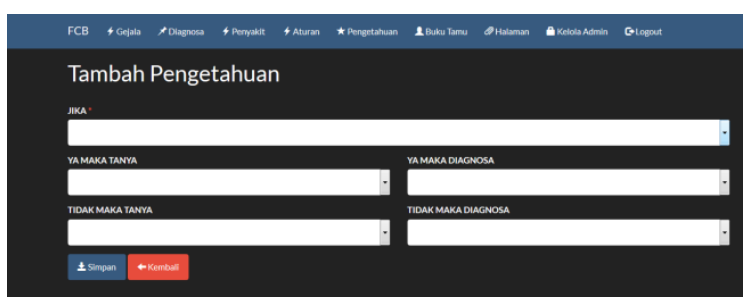

Gambar 13. Halaman Tambah Pengetahuan

6. Halaman Kelola Aturan dan Relasi

Merupakan Halaman Untuk Mengelola Aturan pada sistem. tahap ini yaitu mengisi bobot dari masing-masing penyakit. Padabagian ini terdapat beberapa fitur yaitu Update

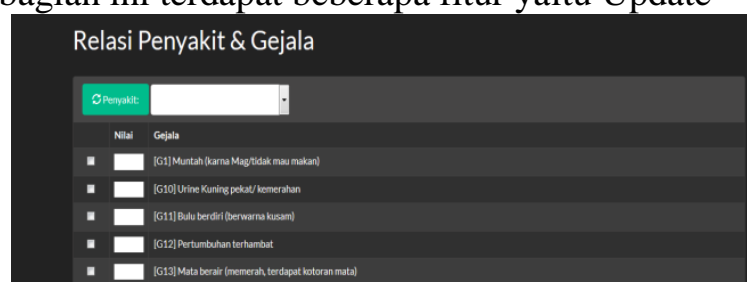

Gambar 14. Halaman Aturan

7. Halaman Konsultasi

Halaman Konsultasi merupakan halaman paling inti yang disuguhkan kepada pengunjung,pada halaman ini pengunjung dapat melakukan konsultasi. pengunjung akan disuguhkan pertanyaan seputar gejala yang dialami oleh anjing yang sakit dan pada kesimpulannya akan diberikan diagnosa penyakit apa yang diderita oleh anjing. berikut tampilan konsultasi

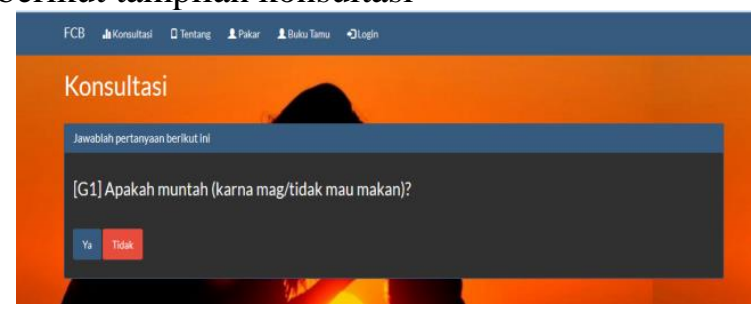

Gambar 15. Halaman Konsultasi

8. Halaman Hasil Konsultasi

Selanjutnya akan ditampilkan hasil Probabilitas yang didapat dari hasil konsultasi yang terjadi dan dilakukan dengan perhitungan dan metode menggunakan Bayes 


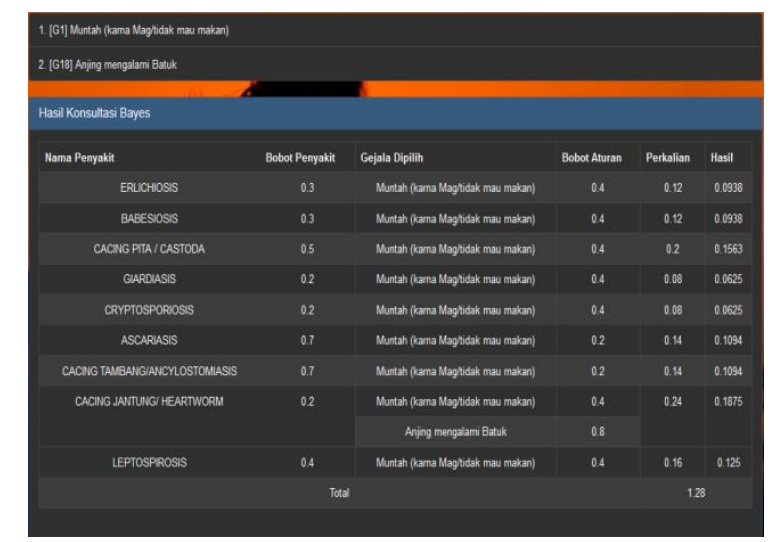

Gambar 16. Halaman Hasil Konsultasi Probabiltas Bayes

i. Pengujian Sistem

a. Pengujian Blackbox fungsinya

Pengujian pada dilakukan untuk memastikan bahwa semua halaman sudah sesuai dengan

b. Pengujian Sistem Dengan Pakar Ahli (Perbandingannya)

Pengujian Sistem dengan Pakar atau ahli bertujuan sebagai sarana perbandingan antara kesimpulan dari sistem dan Kesimpulan diagnosa dari Ahli/Pakar dibidangnya yaitu Dokter Hewan. Dari hasil perbandingan ini didapatkan kesimpulan tentang kelebihan dan kekurangan sistem yang dibuat selain itu juga didapatkan saran yang bermanfaat terutama untuk pengembangan sistem

Proses pengujian sistem dilakukan dengan memberikan kuesioner kepada pakar sekaligus demo program yang telah dibuat. Pada tahap ini akan dimukan jenis penyakit mana yang sesuai dan tidak sesuai dengan Pengetahuan Pakar.

\section{Kesimpulan}

a. Kesimpulan

1. Sistem pakar dapat berguna bagi pemelihara Anjing :

a. Dari hasil pengujian dengan pakar didapatkan hasil bahwa penerapan metode forward chaining dan metode bayes untuk mendiagnosa penyakit akibat parasit pada anjing yang diterapkan pada sistem sesuai dengan ilmu/pengetahuan dari Pakar. Hal ini meyakinkan bahwa nilai kepercayaan pada sistem pakar ini dapat berguna bagi Pemelihara/pecinta hewan peliharaan anjing.

b. Hasil pengujian analisis data dengan Kuesioner untuk mengukur manfaat dari sistem pakar dan hasil yang didapatkan ialah dari jawaban yang diberikan 18 Pemelihara anjing didapat 17 pemelihara anjing yang mengganggap bahwa Sistem Pakar inibermanfaat dari hasil tersebut maka dapat disimpulkan bahwa sistem pakar ini dapat digunakan dan dapat bermanfaat bagi pemelihara.

b. Saran

Untuk penelitian lebih lanjut dapat dikembangkan :

1. Jenis Penyakit dapat dikembangkan lagi bukan hanya mengambil jenis yang sebabkan parasit pada anjing namun menyeluruh semua jenis penyakit anjing.

2. Diperlukan adanya pengembangan lebih lanjut terutama untuk sumber data Penyakit dan gejala, adanya tambahan dari beberapa sumber pakar dan refensi buku bersangkutan diharapkan dapat mengembangkan sistem pakar diagnosa penyakit akibat parasit pada anjing. 


\section{JURNAL TEKNOLOGI INFORMASI}

[E-ISSN 2656-0321]

[Vol 12. No. 1]

Jurnal Keilmutin dan Aplikasi Bidang Teknik Informatilka

[Januari 2018]

\section{DAFTAR PUSTAKA}

[1] Aji,Supriyanto. 2007. Web dengan HTML dan XML. Yogyakarta. Penerbit : Graha Ilmu.

[2] Ariona,Rian.2013. Belajar HTML dan CSS . Penerbit : Ariona.Net

[3] Bunafit,Nugroho. 2008. Aplikasi Pemrograman Web Dinamis Dengan PHP dan MySQL. Yogyakarta. Penerbit : Gava Media.

[4] Dharmojono. 2001. Anjing Pemecahan dan Permasalahan. Jakarta . Penerbit : Penebar Swadaya.

[5] Dian, Purwanti, 2008. Pengertian Website,

[6] http://deyaan.blogspot.com/2008/03/pengertian -website.html . Diakses Tanggal 9 Sepetember 2017.

[7] Hartatik , Putrayasa Ketut, 2015 Sistem Pakar Untuk Mendeteksi Hama Tanaman Jahe Menggunakan Teorema Bayes.

[8] Kadir, A.. 2002. Dasar Pemrograman WEB Dinamis Menggunakan PHP. Yogyakarta. Penerbit: ANDI.

[9] Lily P. 2012. Galeri Lengkap Anjing. Yogyakarta. Penerbit : ANDI

[10] Nugroho,Adi. 2009. Rekayasa Perangkat Lunak Menggunakan UML dan Java. Yogyakarta. Penerbit : ANDI

[11] Nugroho, Adi. 2011. Perancangan dan Implementasi Sistem Basis Data. Yogyakarta. Penerbit: ANDI

[12] Rosa,A. Dan Shalahuddin, M. 2013. Rekayasa Perangkat Lunak Tersruktur Berorientasi Objek. Bandung. Penerbit : INFORMATIKA

[13] Sommerville, Ian . 2011. Software Engineering 9. United States of America: Addison-Wesley.

[14] Sri,Kusumadewi. 2003. Artificial Intelligence (Teknik danAplikasinya). Penerbit: GrahaIlmu.

[15] Subakti,Irfan. 2006. Sistem Berbasis Pengetahuan. Surabaya. Penerbit : Insitut Teknologi 10 November.

[16] Subronto. 2007. Ilmu Penyakit Ternak. Yogyakarta. Penerbit : Univervisitas Gadjah Mada University Press.

[17] Sungkar,Saleha, Staf Pengajar Departemen Parasitologi. 2011. Buku Ajar Parasitologi Kedokteran Edisi Keempat. Penerbit : FKUI

[18] Witari Risna K, Gandihiadi IGK, Kencana Nila IPE, 2013 Sistem Pakar Diagnosa Penyakit Menular Pada Anjing 